\title{
Labour Use on Organic Farms: a Review of Research since 2000
}

\author{
Stefano Orsini ${ }^{*}$ Susanne Padel and Nic Lampkin \\ The Organic Research Centre, Elm Farm, Berkshire, UK \\ ${ }^{*}$ Corresponding author: E-Mail: stefano.o@organicresearchcentre.com
}

Submitted: 7 April 2016 | In revised form: 12 October 2016 | Accepted: 18 May 2018 |

Published: 22 June 2018

\begin{abstract}
Organic farming is frequently associated with claims of more labour requirements than conventional. However, there is a fragmented knowledge about labour use on organic farms in terms of workload, nature and quality of employment provided. In the context of a growing organic demand and a need for more farmers to convert to reach policy targets set by many EU governments, it seems crucial to understand labour trends on organic farms and to what extent labour requirements may hinder the adoption of the organic methods. This paper presents a review of mainly European literature published since 2000. Studies presenting results by farm type usually indicate higher labour use per hectare on organic than conventional arable farms, whereas similar or lower labour use is reported on organic livestock farms, and the results are mixed for other farm types. We have identified in the existing literature two broad dimensions directly related with labour use, which need to be considered in comparative studies, namely farm structure (including farm type, but also farm size and diversification activities), and technical efficiency. These two broad dimensions give us insights into some more specific factors affecting labour use, and how labour is related with productivity and technical efficiency. Overall it appears that claims that labour requirements represent a concrete obstacle to the adoption of the organic methods need to be treated with caution, and more research is needed to understand the role of labour in farmers' decision to convert to organic farming. The review of the nature and quality of employment indicates positive health effects related to higher satisfaction and lower exposure to pesticides in organic agriculture as the most important advantages for farm workers. Overall, there is limited research on whether the organic sector provides better opportunities in terms of job prospects, wages and employment of women.
\end{abstract}

Keywords: farm structure; labour use; organic farming; quality of labour; rural development; technical efficiency

\section{Introduction}

Labour use on organic farms is expected to differ from that on conventional farms [1-3]. In particular, organic farming is frequently associated with claims of high labour requirements, because it needs more resources than conventional for manual and mechanical weed control, is based on a greater diversity of crops at farm level, and organic farmers more often develop marketing and processing activities on farm $[2,4,5]$. However, it is not always the case that more labour is required for individual organic enterprises than conventional $[5,6]$. A variety of study fields-mainly agricultural 
economics, rural sociology, entrepreneurship research and geography-have dedicated research to socio-economic aspects of organic farming, but labour has seldom been the primary focus and different perspectives have been adopted, including technical efficiency, rural development and social justice. The knowledge about labour use on organic farming in terms of workload, labour nature and quality, is fragmented, and there are variable results. There is currently no overview of the outcomes in recent literature. This paper seeks to address this gap.

Gaining an overview of what is known so far seems to be timely, as there is a need for more farmers to convert to organic agriculture in the EU, in order to meet the demand of a growing organic market and to reach the targets for organic production set by many EU governments [7]. It is crucial to understand whether, to what extent and under what circumstances labour requirements on organic farms may be different from conventional farms and may hinder the adoption of the organic methods. Gaining insights into the factors affecting labour use on organic farming is relevant to farmers and policy makers alike. Examining the relation between labour use and technical efficiency and productivity is also critical to identify key research and policy areas for the future development of the organic sector.

The main objective of this paper is to provide an overview of the findings of existing literature, considering the different perspectives that have been used to address this topic. The review considers literature published since 2000 that focused on aspects of labour in organic agriculture in Europe. We have also included a few other studies which are particularly relevant from a methodological point of view.

In the first part of this paper we present the literature that addresses labour use on organic farming, summarising relevant results in one table. We propose a framework outlining the main factors affecting labour use. The second part of the paper focuses on type and quality of employment provided. Finally, some conclusions are presented.

\section{Labour Use on Organic Farm}

\subsection{Labour Use and Farm Structure}

Overall we found only six studies [8-13] comparing labour use per hectare or head of livestock on organic and conventional farms that include a breakdown by farm type. These studies suggest that labour use depends on farm structure, in particular farm type and size. Studies that present results on labour use per hectare or per head of livestock for different farm types are mainly based on FADN data, with Offermann and Nieberg [12] presenting data published before 2000. Lobley et al [10], Tzouvelekas et al [8] and Guesmi et al [9] used primary data gathered through farm surveys.

In Table 1 below we summarise results by farm type. The literature indicates higher labour requirements than conventional for organic arable cropping, general cropping and vineyards [10-13], but exceptions were found in some countries. A similar or lower use of labour per hectare on organic farms is reported for livestock farms, such as dairy farms in England and Wales [11], Austria and France [13], for lowland cattle, Less Favoured Areas(LFA) and sheep in England and Wales [10,11] and also for olive groves in Greece [8]. Mixed results were found for horticulture, general cropping and mixed farming.

Table 1. Breakdown of labour use per hectare (ha) or per head of livestock by farm type OF = organic farms; CF = conventional farms; FTE = Full Time Equivalent.

\begin{tabular}{|c|c|c|c|c|c|}
\hline Farm type & Country & Labour use & Unit & $\begin{array}{l}\text { \% labour difference of } \\
\text { OF compared to CF }\end{array}$ & Author, year \\
\hline \multirow{6}{*}{$\begin{array}{l}\text { General } \\
\text { cropping }\end{array}$} & Austria & $\begin{array}{l}\text { OF: } 1.86 \\
\text { CF: } 1.61\end{array}$ & & $16 \%$ & \multirow{5}{*}{$\begin{array}{c}\text { European } \\
\text { Commission } \\
(2013)[13]\end{array}$} \\
\hline & France & $\begin{array}{l}\text { OF: } 1.43 \\
\text { CF: } 2\end{array}$ & & $-29 \%$ & \\
\hline & Germany & $\begin{array}{l}\text { OF: } 2.7 \\
\text { CF: } 1.61\end{array}$ & FTE/100 ha & $68 \%$ & \\
\hline & Poland & $\begin{array}{l}\text { OF: } 2.81 \\
C F: 2.38\end{array}$ & & $18 \%$ & \\
\hline & Spain & $\begin{array}{l}\text { OF: } 12 \\
\text { CF: } 7.3\end{array}$ & & $64 \%$ & \\
\hline & England and Wales & $\begin{array}{l}\text { OF: } 1.3 \\
\text { CF: } 1\end{array}$ & FTE/100 ha & $30 \%$ & $\begin{array}{l}\text { Moakes et al } \\
(2015)[11]\end{array}$ \\
\hline \multirow[t]{2}{*}{ Arable } & $\begin{array}{l}16 \text { EU countries, } \\
\text { Norway, Switzerland }\end{array}$ & $\begin{array}{l}\text { Higher values } \\
\text { on OF }\end{array}$ & FTE/ha & $\mathrm{n} / \mathrm{a}$ & $\begin{array}{l}\text { Offermann } \\
\text { and Nieberg } \\
(2000) \text { [12] }\end{array}$ \\
\hline & England & $\begin{array}{l}\text { OF: } 2 \\
\text { CF: } 1.7\end{array}$ & FTE/100 ha & $18 \%$ & $\begin{array}{l}\text { Lobley et al } \\
\text { (2009) [10] }\end{array}$ \\
\hline
\end{tabular}


Table 1 continued from previous page

\begin{tabular}{|c|c|c|c|c|c|}
\hline Farm type & Country & Labour use & Unit & $\begin{array}{l}\% \text { labour difference of } \\
\text { OF compared to CF }\end{array}$ & Author, year \\
\hline \multirow{3}{*}{ Horticulture } & $\begin{array}{l}16 \text { EU countries, } \\
\text { Norway, Switzerland }\end{array}$ & $\begin{array}{l}\text { Higher values } \\
\text { on OF }\end{array}$ & FTE/ha & $\mathrm{n} / \mathrm{a}$ & $\begin{array}{c}\text { Offermann } \\
\text { and Nieberg } \\
(2000)[12]\end{array}$ \\
\hline & England & $\begin{array}{l}\text { OF: } 79.2 \\
\text { CF: } 73.3\end{array}$ & FTE/100 ha & $8 \%$ & $\begin{array}{l}\text { Lobley et al } \\
(2009)[10]\end{array}$ \\
\hline & England and Wales & $\begin{array}{l}\text { OF: } 24.4 \\
C F: 45.8\end{array}$ & FTE/ha & $-47 \%$ & $\begin{array}{c}\text { Moakes et al } \\
(2015)[11]\end{array}$ \\
\hline Olive groves & Greece & $\begin{array}{l}\text { OF: } 4,087 \\
\text { CF: } 4,863\end{array}$ & Drachmas/ha & $-16 \%$ & $\begin{array}{c}\text { Tzouvelekas } \\
\text { et al } \\
(2001)[8]\end{array}$ \\
\hline Grape & Spain & $\begin{array}{l}\text { OF: } 458.93 \\
C F: 287.76\end{array}$ & hours/ha & $58 \%$ & $\begin{array}{c}\text { Guesmi et al } \\
(2012)[9]\end{array}$ \\
\hline \multirow{3}{*}{ Dairy } & England & $\begin{array}{l}\text { OF: } 3.1 \\
\text { CF: } 4.8\end{array}$ & FTE/100 ha & $-35 \%$ & $\begin{array}{l}\text { Lobley et al } \\
(2009)[10]\end{array}$ \\
\hline & $\begin{array}{l}\text { Austria } \\
\text { France } \\
\text { Germany }\end{array}$ & $\begin{array}{l}\text { OF: } 0.1 \\
C F: 0.1 \\
\text { OF: } 0.04 \\
C F: 0.04 \\
\text { OF: } 0.05 \\
C F: 0.04\end{array}$ & FTE/cow & $\begin{array}{l}0 \% \\
25 \%\end{array}$ & $\begin{array}{c}\text { European } \\
\text { Commission } \\
(2013)[13]\end{array}$ \\
\hline & England and Wales & $\begin{array}{l}\text { OF: } 2.2 \\
\text { CF: } 2.5\end{array}$ & FTE/100 ha & $12 \%$ & $\begin{array}{c}\text { Moakes et al } \\
(2015)[11]\end{array}$ \\
\hline \multirow{3}{*}{ Mixed } & $\begin{array}{l}16 \text { EU countries, } \\
\text { Norway, Switzerland }\end{array}$ & $\begin{array}{l}\text { Higher values } \\
\text { on OF }\end{array}$ & FTE/ha & $\mathrm{n} / \mathrm{a}$ & $\begin{array}{c}\text { Offermann } \\
\text { and Nieberg } \\
(2000)[12]\end{array}$ \\
\hline & England & $\begin{array}{l}\text { OF: } 6 \\
\text { CF: } 4.4\end{array}$ & FTE/100 ha & $36 \%$ & $\begin{array}{l}\text { Lobley et al } \\
(2009)[10]\end{array}$ \\
\hline & England and Wales & $\begin{array}{l}\text { OF: } 1.5 \\
\text { CF: } 1.5\end{array}$ & FTE/100 ha & $0 \%$ & $\begin{array}{c}\text { Moakes et al } \\
(2015)[11]\end{array}$ \\
\hline \multirow[t]{2}{*}{$\begin{array}{l}\text { Lowland cattle } \\
\text { and sheep }\end{array}$} & England & $\begin{array}{l}\text { OF: } 2.9 \\
C F: 5.6\end{array}$ & FTE/100 ha & $-48 \%$ & $\begin{array}{l}\text { Lobley et al } \\
(2009)[10]\end{array}$ \\
\hline & England and Wales & $\begin{array}{l}\text { OF: } 1.2 \\
\text { CF: } 1.3\end{array}$ & $£ /$ ha & $8 \%$ & $\begin{array}{c}\text { Moakes et al } \\
(2015)[11]\end{array}$ \\
\hline \multirow[t]{2}{*}{$\begin{array}{l}\text { LFA cattle and } \\
\text { sheep }\end{array}$} & England & $\begin{array}{l}\text { OF: } 2.9 \\
\text { CF: } 5.2\end{array}$ & FTE/100 ha & $-44 \%$ & $\begin{array}{l}\text { Lobley et al } \\
(2009)[10]\end{array}$ \\
\hline & England and Wales & $\begin{array}{l}\text { OF: } 1.1 \\
\text { CF: } 1.1\end{array}$ & FTE/100 ha & $0 \%$ & $\begin{array}{c}\text { Moakes et al } \\
(2015)[11]\end{array}$ \\
\hline \multirow[t]{2}{*}{$\begin{array}{l}\text { Pigs and } \\
\text { poultry }\end{array}$} & $\begin{array}{l}16 \text { EU countries, } \\
\text { Norway, Switzerland }\end{array}$ & $\begin{array}{l}\text { Similar values on } \\
\text { OF and CF }\end{array}$ & FTE/ha & $\mathrm{n} / \mathrm{a}$ & $\begin{array}{c}\text { Offermann } \\
\text { and Nieberg } \\
(2000)[12]\end{array}$ \\
\hline & England & $\begin{array}{l}\text { OF: } 38.5 \\
\text { CF: } 29.4\end{array}$ & FTE/100 ha & $31 \%$ & $\begin{array}{l}\text { Lobley et al } \\
\text { (2009) [10] }\end{array}$ \\
\hline
\end{tabular}


Only some of the studies reviewed provide an explanation of the differences in labour use on organic and conventional farming. For example, lower labour use on organic olive grove farms in Greece compared with conventional was explained with less labour required to harvest the lower levels of olive production [8]. Labour use per animal in livestock systems is similar or higher on organic farms, but lower stocking rates and lower number of animals on organic farms can result in less total labour use per hectare [12].

A distinct group of studies report data of labour use per farm, rather than per hectare or head of animals and the results within this group are mixed too. Three studies report lower labour use on organic dairy farms compared to conventional [14-17], and three suggest the opposite $[1,18,19]$. Likewise on organic arable cropping both cases of higher $[18,20,21]$ and lower $[20,22,23]$ labour use than conventional farms are reported.

However, higher labour input per farm does not necessarily imply higher labour input per hectare, especially if organic and conventional samples are unbalanced in terms of average farm size. For example, the research conducted in the UK and the Republic of Ireland by Morison et al [24] indicates that small organic farms use proportionally more labour per 100 ha than large organic farms. It was found that the organic sector employs 35\% more labour per farm, but conventional farms employ $80 \%$ more labour per hectare, as organic farms within the sample were considerably larger than conventional [24].

The presence of on-farm diversification activities can also impact on labour use. Organic farms are more likely to engage in diverse crop production and activities, such as processing and direct marketing, which impact on labour organisation and increase workloads on farms [10,24-26].

\subsection{Labour Use and Technical Efficiency}

Some studies comparing organic and conventional farms model different farm inputs including labour to estimate technical efficiency. From an agricultural economic perspective, technical efficiency is the ratio of the farm output over the 'frontier' (i.e. maximum output) that may be obtained with given inputs and technology [27].

Efficiency studies provide information about labour input, labour efficiency and labour elasticity, which measures the responsiveness of production to a change in levels of labour. Different models are used when comparing technical efficiency of organic and conventional farms in order to reduce self-selection bias, including matching models $[23,28,29]$, metafrontier models $[14,22,30]$, and selectivity models $[16,17]$.

Figures of labour input on farms included in the efficiency literature are also varied, with cases of higher or lower labour requirements on organic farms. For example, organic olive farms in Greece [8] and organic dairy farms in Germany [14] seem to use respectively less or similar labour than their conventional counterparts. Similar to the studies reported above, labour requirements on arable farms are in most cases higher on organic farms [20-23,31,32].

Two studies providing specific figures of labour efficiency show contrasting results. Lansink et al [33] indicate higher labour efficiency on organic crop and livestock farms in Finland, whereas Tzouvelakes et al [8] found lower labour efficiency on organic olive groves in Greece.

As for type of labour used (i.e. family versus hired labour), Tzouvelekas et al [21] hypotesized suboptimal effort exerted by hired labour as opposed to family labour which mitigates any possible agency problems. A literature review on technical efficiency in organic and conventional farms by Lakner and Breustedt [34] does not confirm this hypothesis, and shows mixed results, with five studies revealing that family labour is in fact less efficient than hired labour, and three other studies suggesting the opposite.

The efficiency literature provides also interesting information about production elasticity of labour. Five studies indicate a higher production elasticity of labour on organic than conventional farms $[8,9,19,23,32]$, whereas five other studies found a lower value of elasticity on organic farms $[15,16,20,21,28]$. This might seem to be somewhat counterintuitive, given that organic farming is traditionally thought to be more labour-intensive than conventional farming, and we would expect output to be more sensitive to changes in labour on organic than conventional farms. However, none of the studies reviewed provide a reasonable explanation for this result.

Another relevant component of technical efficiency which is likely to have an impact on labour requirements is represented by time after conversion. Sipiläinen and Lansink [17] and Lakner et al [35] found that technical efficiency of converting farms was lower than efficiency of established organic farms and increased after six or seven years since conversion, a period during which a comparable conventional farm would have increased its technical efficiency. This is the time for learning the organic methods, following the decision to convert. More empirical studies are needed to understand how labour use normally evolves over time and how it relates to the learning of organic practices.

The differences in farm management between organic and conventional farming-i.e. weed and pest control, fertility building, tillage, livestock management-are expected to be a critical factor contributing to labour requirements [4]. It is reported in some studies [29,33] that organic farming is related to lower labour productivity even when labour is employed efficiently, because labour on organic farms might be used for low productive practices, such as manual weed control. Research into the development and adoption of labour saving management practices targeted at organic farming seems to be critical in order to reduce labour requirements $[5,36]$ and improve its productivity and efficiency but is very rare. 


\subsection{Labour Use in Farmers' Decision-Making}

Despite the presumed lower productivity of labour on organic farms, the variety of empirical results on labour use that we have found across different farm types suggests that claims that labour requirement represents a concrete obstacle to the adoption of organic farming need to be treated with caution.

Darnhofer et al [37] found that labour was not a barrier to adopting the organic methods, despite being perceived as a bottleneck by farmers. They concluded that high labour requirements on organic farms reflect more a belief than a decision rule [37].

Likewise, some authors contend that labour seems not to be crucial in farmers' decision to expand or reduce farm size [38], whether organic or not, and that the higher labour requirement on organic farming is of intermediate importance as a reason for opting out of organic farming [3]. Type of labour (hired versus family labour) was found to be related with the adoption of organic farming by Larsen [39], who suggested that the probability to adopt organic methods increases with the share of hired labour.

Because of the limited literature, it is not possible to draw firm conclusions about the importance of labour in organic farmer's decision-making process, where external factors not considered in the literature are also likely to be important, such as labour availability.

\subsection{Limitations of the Existing Studies}

The different methodologies in the studies reviewed and variations in data quality and sample size might explain in part the differences in the results presented above. Most studies reviewed are based on secondary data, mainly FADN, which has the advantage to give comparable results across Europe. However, such studies might have some sampling biases, because organic farming is not a sampling criterion in FADN and therefore the organic samples in each country are not necessarily representative of the sector.

Labour use is usually expressed as working time, either in hours or Full Time Equivalents (FTE), or as a cost item. The use of working hours or Full Time Equivalents gives a meaningful representation of the labour force that takes the different contribution of full-time, part-time, casual and seasonal workers [10] into account, but it is based on estimates of hours worked and there may be uncertainty in estimating the Full Time Equivalents value of seasonal or causal workers. The measurement of labour as a cost item is particularly relevant from a farm financial perspective, but imputed values based on estimates are likely to be used for family and unpaid labour.

It is difficult to compare the results of studies that use different units of measuring labour, such as per farm, per hectare or per animal. While data per farm provide a useful indication of employment created at aggregate level, they might be misleading as a representation of the labour needed by the two different farming methods. This is especially true as the average farm size of the two groups is usually different across the studies reviewed (e.g. [9,16,24,32]), and higher labour input per farm does not necessarily imply higher labour input per hectare. As far as livestock systems are concerned, it is useful to consider also labour use per animal together with labour use per hectare. These two measurements can give contradicting results: more or similar labour per animal seems to be required on organic compared to conventional farms [11], but labour use per farm or per hectare might be lower on organic systems because of the lower stocking rate and number of animals $[11,12]$.

Finally, and related to the arguments above, organic and conventional farms need to be 'comparable' when studying labour use on organic versus conventional farms. Nieberg et al [40] proposed a framework for comparative studies, based on the concept of similar endowment of production factors, which ensures that differences in labour use on organic and conventional farms are indeed attributed to their management system and not to differences in endowment of production factors including farm type, farm size and farm location. Based on this framework, Moakes et al [11] used a method of clustering where each organic farm was matched with a cluster of conventional farms based on the resource endowment indicators including farm type, region, LFA status, utilisable agricultural area, farm business size and milk quota held. Other studies were found that analyse comparable farm pairs, with Flubacher [28] and Mayen et al [29] using Propensity Score Matching, and Tiedemann and Latacz-Lohmann [23] using Euclidean-Distance Matching. The other studies reviewed just compare a sample group of organic farms with all conventional farms of another sample, without taking into account the potential structural differences between organic and conventional farms, which are likely to affect the overall farm organisation including labour use.

\subsection{A Framework for Comparative Studies of Labour Use on Organic and Conventional Farms}

Despite the limitations presented in Section 2.4, we can identify in the existing literature two broad dimensions which need to be considered in future comparative studies of labour use on organic and conventional farms, as explained below:

- Farm structure affects the organisation of labour and tends to be more complex on organic farms, which are usually based on more diversified crops, rotations and activities $[4,10,24,30,41]$. While organic arable farms are usually more labour intensive than conventional [10-13], labour requirements on organic livestock farms are often found to be lower than their conventional counterparts [10-14]. Organic farms are more likely to engage in value adding activities such as processing and direct marketing, which increases labour requirements [10,24-26]. Finally, small organic farms seem to use proportionally more labour per 
100 ha than large organic farms [24], and some benefits of specialisation and economies of scale might be lost in part on organic farms because of the greater diversity of farm structure compared to conventional farms [10].

- The efficiency literature revealed many cases where organic production is less sensitive to changes in labour than conventional $[15,16,20,21,28]$. This is surprising since labour as an input is thought to be especially important for organic farming. Also, labour efficiency was found to be both higher and lower on organic compared with conventional farms $[8,33]$. The sophisticated models adopted cannot explain the mixed results, but together these studies challenge the widely held belief about lower labour efficiency and productivity on organic farms.

Organic and conventional farms need to be 'comparable' when comparing labour use on organic versus conventional farms. Nieberg et al [40] proposed a general methodology for comparative studies based on identical farm type, similar endowment of production factors such as farm size, and same region. Based on this approach, a clustering method and farm pairs analysis were performed more recently by Moakes [11] and in some efficiency studies [23,28,29].

The two broad dimensions of farm structure and technical efficiency give us insights into some more specific factors affecting labour use, and how labour is related with productivity and efficiency. However, more research is needed to understand the relevance of labour in farm management decision, in particular in farmer's decision to convert to organic farming.

In the next sections we will review aspects related with type of employment and quality of labour, which may play a role in the decision to convert to organic farming and which are particularly important from a rural development perspective.

\section{Type of Employment Provided and Quality of Labour}

The quality of working conditions on organic farms is covered by the IFOAM 'Principle of Fairness', which states that: "Organic farming should provide everyone involved with a good quality of life" [42]. Most European standards require that organic farmers must comply with the UN Convention on Human Rights and the International Labour Organisation standards.

Based on the Jansen' framework [4] which broadly identifies terms of employment, working conditions, content of work and labour relations as the main elements of labour quality, we frame this section around the following specific aspects of employment: seasonal versus permanent jobs, farm worker's health and work satisfaction, wages, job prospects and gender differences. Our objective here is to understand based on the existing studies to what extent social considerations related to organic agriculture are implemented or remain a vague objective.

\subsection{Seasonal versus Permanent Jobs and Job Prospects}

According to some studies, the share of hired labour compared to family labour often seems to be higher on organic than conventional farms $[4,8,9,18,39]$. Jansen [4] questioned whether the increase in hired labour reflects an increase in hired permanent labour, assuming that a high reliance on seasonal workers may reduce the overall benefit of a business to rural development. In 2000, he found little evidence suggesting that this increase is partly in hired permanent labour and partly in seasonal or casual labour, and stated that more studies were needed to draw firm conclusions [4]. Only very few studies have further investigated this question since.

Many agricultural sectors in Europe are now dependent upon low-cost seasonal labour. In particular horticulture, which faces with the most acute labour cost pressures, is likely to take advantage of low cost of seasonal labour [43]. There are concerns in relation to the working conditions for seasonal migrant workers in agriculture, who are particularly vulnerable to exploitation $[44,45]$. A Dutch study by Gardebroek et al [20] suggests that both organic and conventional arable farms are reliant on temporary hired labour at periods of peak demands, with no substantial difference between the two sectors.

Two studies in England [10] and France [46] both point to higher levels of temporary or casual work on organic farms. In particular, the French study by Cédric [46] indicates that organic farms were in general more likely to employ people on temporary contracts and the likelihood actually increased from 2002 to 2009 . However, there was considerable variation depending on the location and farm type, with the proportion of workers on temporary contracts ranging from $57 \%$ in Alpes Maritimes to $90 \%$ in Vaucluse. In particular, organic horticulture and cereals saw the greatest increase in temporary contracts over this period, and contracts in the organic sector were likely to be an average of 20 days shorter than in the conventional sector [46]. Apart from these studies, there is a marked lack of research on the type of labour on organic farms, and it remains difficult to come to any conclusions regarding the differences in use of seasonal versus permanent labour on organic and conventional farming. Crucially, in many cases it may well be other factors that determine the type of labour used, rather than simply the farm management system. These might be related to the specific industry, national regulations on labour and individual farms' financial circumstances.

\subsection{Farmer and Farm Worker Health in Organic and Conventional Farming}

It is very likely that pesticide exposure is lower on organic farms because of the lower use of pesticides, which represents an important advantage for workers on organic farms compared to those working in conventional farms, especially in crops such as fruit and vegetables with typically high pesticide application rates [47]. 
Regarding mental health, French studies by Nettier et al [2], Dupré et al [48] and Navarrete et al [49] point to higher levels of satisfaction among organic compared to conventional farmers, due to greater personal fulfilment and recognition of their work. A study by Cross [44] et al suggests that workers on organic farms are happier than those employed on conventional farms, indicated by better scores in a 'Short Depression Happiness Scale', mainly because of the increased variety of tasks performed each day. However, the other three measures of mental health (i.e. Short Form 36, EuroQol EQ-5D and the Visual Analogue Scale) pointed to no significant difference between organic and conventional workers. Both the organic and conventional sector workers had lower than average scores for the other three measures of mental health, suggesting that overall the mental health of farm workers - regardless of the sector - is still worse than in other professions [38].

\subsection{Wages}

The study conducted by Lobley et al [10] in England found that salaries per FTE on organic farms in the sample of their study were on average $17 \%$ lower than on conventional farms. However, looking at the figures in more details, it appears that the lower salary per FTE on organic farms is largely accounted for by lower family wages and employment of staff as shop assistants or in on-farm food processing. The authors cautioned that salary figures should be interpreted carefully, because farmers do not pay themselves a wage which is easily comparable with salaried workers.

Figures from the Farm Income report in England and Wales by Moakes et al [11] show that value of farmer and family labour, labour income per Annual Labour Unit, and family labour income per Family Work Unit are all greater on organic than conventional farms across all farm types, with the exception of horticulture where the farm income is lower for organic.

A study conducted in France [46] found that average annual organic salaries were $60 \%$ higher than in the conventional sector, although from 2002 to 2009 they only increased by $35 \%$ compared to $56 \%$ on conventional farms. This suggests that the wages on conventional farms may be catching up with the organic sector.

Given the very limited number of studies and their contradictory findings, the literature relating to wages is not conclusive, as it is the analysis of income per unit of labour carried out by the European Commission in five EU countries [13], which shows no clear pattern of income per annual work unit on organic versus conventional farms.

\subsection{Employment of Women}

Overall there is very little research on the employment of women in organic sector and also very few gender studies in this area.

Jansen argued that women are more involved in organic agriculture than in conventional but did not provide any empirical evidence [4]. Amongst the studies reviewed here, only three looked at employment of woman. In a survey conducted in England, Lobley et al [10] found that a smaller proportion of the organic farmers were women compared to conventional, but female respondents from the organic sector were younger than those from the conventional (50 compared with 57 years old). A study on family farms in Switzerland found that the farm woman is more involved in family work than farm work, both in conventional and organic farming, but to a smaller extent in the latter case [50].

The Farm Economics Brief published by the European Commission in 2013 [13] on the financial performance of organic agriculture in the $\mathrm{EU}$, indicates that there was no difference in the share of male and female farm managers in the EU-27 between organic and non-organic farms.

\subsection{Labour Use on Organic Farms and Rural Development}

Since organic farming has generally been associated with greater labour demand than conventional, it could be assumed that policies that encourage organic conversion will consequently have positive effects on rural employment $[25,51,52]$. However, as we have shown in the previous sections, it is not always the case that organic farms have greater labour requirements then conventional, and very few studies address the relationship between organic farming and rural development.

Lobley et al. found in England that differences in employment generated reflect the distinctive business configurations of organic and conventional farms, and not necessarily the adoption of organic farming per se [10]. In particular, they found that the positive effects of organic farms on rural employment are related to higher incidence of on-farm diversification activities and more hired labour compared to conventional farms, which was found to rely more on family labour.

Other studies also found that organic farms employ more non-family labour $[4,8,9,18,39]$ and this might have positive rural development implications. However, from a rural development perspective it is also important to consider the nature of any jobs created, in particular remuneration and permanence, which remain largely unexplored.

A study conducted in France [53] found that rural development policies for the programming period 2007 to 2013 related to organic farming had very limited effects on changes in labour use. The explanations given by the authors is that conventional farms choosing to convert may have been the ones that already implemented practices close to organic or that any effect on labour use may be observed after the programming period considered [53].

Most of the existing economic studies only look at labour as a production unit which needs to be minimised, and overlook the output generated in financial and employment terms, thus considering labour only as an obstacle to the adoption of the organic methods. However, from a rural 
development perspective it is important to consider the financial output generated per labour unit. Moakes et al [11] found in England and Wales that even though yield levels might be lower on organic farms, the financial output generated per labour unit is similar across farm types, with slightly better performance for organic farms with the exception of the horticulture sector.

\section{Conclusions}

In this paper we have reviewed differences in labour use on organic and conventional farming in Europe in the scientific literature published since 2000 and outlined some key factors affecting labour use. Overall, labour use on organic farms has received very little attention in the literature, despite the potential implications for farm management and for rural development.

Taken together, the existing studies show variable results and do not confirm the widely held belief that organic farming always requires more labour than conventional. Higher labour use per hectare is more often reported on organic than conventional arable farms, whereas similar or lower labour use per hectare is usually reported on organic livestock farms, and the results are mixed for other farm types.

Our review highlights the importance of considering farm structure in future research, as labour use appears to change with farm type, with the endowment of production factors in particular farm size, and with the presence or absence of diversification activities. The efficiency studies reveal that labour efficiency is not necessarily lower on organic farms, and that in many cases production is less sensitive to changes in labour use on organic than

\section{References and Notes}

[1] Mamardashvili P, Emvalomatis G, Jan P, et al. Environmental performance and shadow value of polluting on Swiss dairy farms. Journal of Agricultural and Resource Economics. 2016;41(2):225-246.

[2] Nettier B, Dufour A, Chabrat S, Madelrieux S. Conversion to organic farming and consequences on work organisation and work perception. In: The 10th European IFSA Symposium. Aarhus, Denmark; 2012.

[3] Flaten O, Lien G, Koesling M, Løes AK. Norwegian farmers ceasing certified organic production: Characteristics and reasons. Journal of Environmental Management. 2010;91(12):2717-2726. doi:10.1016/j.jenvman.2010.07.026.

[4] Jansen K. Labour, livelihoods and the quality of life in organic agriculture in Europe. Biological agriculture \& horticulture. 2000;17(3):247278. doi:10.1080/01448765.2000.9754845.

[5] Sørensen CG, Madsen NA, Jacobsen BH. Organic farming scenarios: operational analysis and costs of implementing innovative technologies. Biosystems engineering. 2005;91(2):127-137. doi:10.1016/j.biosystemseng.2005.03.006.

[6] Lampkin N, Pearce B, Leake A, Creissen H, Gerrard CL, Gerling $R$, et al. The role of agroecology in sustainable intensification. Elm Farm, UK: Land Use Policy Group, Organic Research Centre and Game \& Wildlife Conservation Trust; 2015.

[7] Meredith S, Willer H. Organic in Europe-prospects and developments. Brussels, Belgium: IFOAM EU Group and FiBL; 2014.

[8] Tzouvelekas V, Pantzios CJ, Fotopoulos C. Technical efficiency of alternative farming systems: the case of Greek organic and conventional olive-growing farms. Food Policy. 2001;26(6):549-569. conventional farms.

The role of labour in farmers' decision to adopt the organic methods remains ambivalent and very little researched. Some studies show that labour requirement on organic versus conventional farms does not reflect a decision rule for adopting or not adopting organic farming $[3,37,38]$. External factors, in particular labour availability, are likely to become increasingly relevant and should be considered in future research. We conclude that claims that labour requirements represent a concrete obstacle to the adoption of organic farming need to be treated with caution.

The question of the relationship between labour use on organic farms and rural development points to a more general theme which goes beyond the amount of labour used and involves the nature and quality of employment generated as well as gender issues. More positive health effects related to higher satisfaction and lower exposure to pesticides seem to be the most important advantages for farm workers. However, there is little research on whether the organic sector provides better opportunities in terms of wages, job prospects and employment of woman or young people. The inclusion of social standards regarding social sustainability in organic agriculture has sporadically been discussed, and criteria should be codified to make sure that the organic sector is also socially sustainable and can therefore encourage the conversion of non-organic farms.

\section{Acknowledgements}

We would like to thank Catherine Gerrard and Oliver Rubinstein for their input into earlier versions of the paper. We would also like to thank the Editor, and the two anonymous referees for their helpful comments.

doi:10.1016/S0306-9192(01)00007-0.

[9] Guesmi B, Serra T, Kallas Z, Roig JMG. The productive efficiency of organic farming: the case of grape sector in Catalonia. Spanish Journal of Agricultural Research. 2012;(3):552-566. doi:10.5424/sjar/2012103-462-11.

[10] Lobley M, Butler A, Reed M. The contribution of organic farming to rural development: An exploration of the socio-economic linkages of organic and non-organic farms in England. Land Use Policy. 2009;26(3):723-735. doi:10.1016/j.landusepol.2008.09.007.

[11] Moakes S, Lampkin N, Gerrard C. Organic farm incomes in England and Wales. Newbury, UK: Organic Research Centre; 2009.

[12] Nieberg $H$, Offermann F. Economic performance of organic farms in Europe. Universität Hohenheim, Stuttgart-Hohenheim; 2000.

[13] Organic versus conventional farming, which performs better financially? European Commission; 2013.

[14] Breustedt G, Latacz-Lohmann U, Tiedemann T. Organic or conventional? Optimal dairy farming technology under the EU milk quota system and organic subsidies. Food Policy. 2011;36(2):223-229. doi:10.1016/j.foodpol.2010.11.019.

[15] Kargiannis G, Salhofer K, Sinabell F. Scale Efficiency in Organic and Conventional Dairy Farming. In: Congress Papers. 124119. Trento, Italy: Italian Association of Agricultural and Applied Economics (AIEAA); 2012.

[16] Kumbhakar SC, Tsionas EG, Sipiläinen T. Joint estimation of technology choice and technical efficiency: an application to organic and conventional dairy farming. Journal of Productivity Analysis. 2009;31(3):151-161. doi:10.1007/s11123-008-0081-y.

[17] Sipiläinen T, Oude Lansink A, et al. Learning in organic farming-an application on Finnish dairy farms. In: XIth Congress of the EAAE 
(European Association of Agricultural Economists). Copenhagen, Denmark; 2005. pp. 24-27.

[18] Schader C. Cost-effectiveness of organic farming for achieving environmental policy targets in Switzerland. Institute of Biological, Environmental and Rural Sciences, Aberystwyth, Aberystwyth University, Wales. Research Institute of Organic Agriculture (FiBL), Frick, Switzerland; 2009.

[19] Lakner S. Technical efficiency of organic milk-farms in Germany the role of subsidies and of regional factors. Agronomy Research. 2009;7(Special issue II):632-639.

[20] Gardebroek C, Chavez MD, Lansink AO. Analysing production technology and risk in organic and conventional Dutch arable farming using panel data. Journal of Agricultural Economics. 2010;61(1):6075. doi:10.1111/j.1477-9552.2009.00222.x.

[21] Tzouvelekas V, Pantzios CJ, Fotopoulos C. Measuring multiple and single factor technical efficiency in organic farming: The case of Greek wheat farms. British Food Journal. 2002;104(8):591-609. doi:10.1108/00070700210425967.

[22] Sipiläinen T, Huhtala A. Opportunity costs of providing crop diversity in organic and conventional farming: would targeted environmental policies make economic sense? European Review of Agricultural Economics. 2012;40(3):441-462. doi:10.1093/erae/jbs029.

[23] Tiedemann T, Latacz-Lohmann U. Production risk and technical efficiency in organic and conventional agriculture-the case of arable farms in Germany. Journal of Agricultural Economics. 2013;64(1):7396. doi:10.1111/j.1477-9552.2012.00364.x.

[24] Morison J, Hine R, Pretty J. Survey and analysis of labour on organic farms in the UK and Republic of Ireland. International Journal of Agricultural Sustainability. 2005;3(1):24-43. doi:10.1080/14735903.2005.9684742.

[25] Darnhofer I. Organic farming and rural development: Some evidence from Austria. Sociologia Ruralis. 2005;45(4):308-323. doi:10.1111/j.1467-9523.2005.00307.x.

[26] Knickel K, Renting $H$. Methodological and conceptual issues in the study of multifunctionality and rural development. Sociologia ruralis. 2000;40(4):512-528. doi:10.1111/1467-9523.00164.

[27] Battese GE, Coelli TJ. Frontier production functions, technical efficiency and panel data: with application to paddy farmers in India. Journal of productivity analysis. 1992;3(1-2):153-169. doi:10.1007/BF00158774.

[28] Flubacher M, Sheldon G, Müller A, et al. Comparison of the Economic Performance between Organic and Conventional Dairy Farms in the Swiss Mountain Region Using Matching and Stochastic Frontier Analysis. Journal of Socio-Economics in Agriculture (Until 2015: Yearbook of Socioeconomics in Agriculture). 2015;7(1):76-84.

[29] Mayen CD, Balagtas JV, Alexander CE. Technology adoption and technical efficiency: organic and conventional dairy farms in the United States. American Journal of Agricultural Economics. 2010:92(1):181-195. doi:10.1093/ajae/aap018.

[30] Beltrán-Esteve M, Reig-Martínez E. Comparing conventional and organic citrus grower efficiency in Spain. Agricultural Systems. 2014;129:115-123. doi:10.1016/j.agsy.2014.05.014.

[31] Madau FA. Technical efficiency in organic and conventional farming: Evidence from Italian cereal farms. Agricultural Economics Review. 2007;8(1):5-21.

[32] Serra T, Goodwin BK. The efficiency of Spanish arable crop organic farms, a local maximum likelihood approach. Journal of Productivity Analysis. 2009;31(2):113-124. doi:10.1007/s11123-008-0124-4.

[33] Lansink AO, Pietola K, Bäckman S. Effciency and productivity of conventional and organic farms in Finland 1994-1997. European Review of Agricultural Economics. 2002;29(1):51-65. doi:10.1093/erae/29.1.51.

[34] Lakner S, Breustedt G. Efficiency Analysis of Organic Farming Systems-A Review of Concepts, Topics, Results and Conclusions. German Journal of Agricultural Economics. 2017;66(2):85-108.

[35] Lakner S, von Cramon-Taubadel S, Brümmer B. Technical efficiency of organic pasture farming in Germany: The role of location economics and of specific knowledge. Renewable Agriculture and Food Systems. 2012;27(3):228-241. doi:10.1017/S1742170511000330.

[36] Casagrande M, Peigné J, Payet V, Mäder P, Sans FX, BlancoMoreno JM, et al. Organic farmers' motivations and challenges for adopting conservation agriculture in Europe. Organic Agriculture. 2016;6(4):281-295. doi:10.1007/s13165-015-0136-0.

[37] Darnhofer I, Schneeberger W, Freyer B. Converting or not converting to organic farming in Austria: Farmer types and their rationale. Agriculture and human values. 2005;22(1):39-52. doi:10.1007/s10460004-7229-9.

[38] Brenes-Munoz T, Lakner S, Bruemmer B. What influences the growth of organic farms? Evidence from a panel of organic farms in Germany. German Journal of Agricultural Economics. 2016;65(1):1-15.

[39] Larsen K, Foster K, et al. Technical efficiency among organic and conventional farms in Sweden 2000-2002: a counterfactual and self selection analysis. In: American Agricultural Economics Association Annual Meeting. Providence, RI, USA; 2005. pp. 24-27.

[40] Nieberg H, Offermann F, Zander K, et al. Organic farms in a changing policy environment: impacts of support payments, EU-enlargement and Luxembourg reform. Stuttgart, Germany: Universität Hohenheim, Institut für Landwirtschaftliche Betriebslehre; 2007.

[41] Dinis I, Ortolani L, Bocci R, Brites C. Organic agriculture values and practices in Portugal and Italy. Agricultural Systems. 2015;136:39-45. doi:10.1016/j.agsy.2015.01.007.

[42] IFOAM. IFOAM Basic Standards. Bonn, Germany; 2002.

[43] Rogaly B. Intensification of workplace regimes in British horticulture: the role of migrant workers. Population, Space and Place. 2008;14(6):497-510. doi:10.1002/psp.502.

[44] Cross P, Edwards RT, Hounsome B, Edwards-Jones G. Comparative assessment of migrant farm worker health in conventional and organic horticultural systems in the United Kingdom. Science of the Total Environment. 2008;391(1):55-65. doi:10.1016/j.scitotenv.2007.10.048.

[45] Ruhs M, Anderson B. Semi-compliance and illegality in migrant labour markets: an analysis of migrants, employers and the state in the UK. Population, space and place. 2010;16(3):195-211. doi:10.1002/psp.588.

[46] Chambru C. Évaluation des effets propres de la conversion à l'agriculture biologique sur l'emploi. Ecole Polytechnique; 2011.

[47] Seufert V, Ramankutty N. Many shades of gray-The contextdependent performance of organic agriculture. Science advances. 2017;3(3):e1602638. doi:10.1126/sciadv.1602638.

[48] Dupré L, Lamine C, Navarrete M. Short Food Supply Chains, Long Working Days: Active Work and the Construction of Professional Satisfaction in French Diversified Organic Market Gardening. Sociologia Ruralis. 2017;57(3):396-414. doi:10.1111/soru.12178.

[49] Navarrete M, Dupré L, Lamine C. Crop management, labour organization, and marketing: three key issues for improving sustainability in organic vegetable farming. International journal of agricultural sustainability. 2015;13(3):257-274. doi:10.1080/14735903.2014.959341.

[50] Reissig L, Kohler A, Rossier R. Workload on organic and conventional family farms in Switzerland. Organic Agriculture. 2016:6(3):225-242. doi:10.1007/s13165-015-0131-5.

[51] Seyfang G. Ecological citizenship and sustainable consumption: Examining local organic food networks. Journal of rural studies. 2006;22(4):383-395. doi:10.1016/j.jrurstud.2006.01.003.

[52] Renting H, Marsden TK, Banks J. Understanding alternative food networks: exploring the role of short food supply chains in rural development. Environment and planning A. 2003;35(3):393-411. doi:10.1068/a3510.

[53] Desjeux Y, Dupraz P, Latruffe L, Maigne E, Cahuzac E, et al. Evaluating the impact of rural development measures on farm labour use: a spatial approach. In: EAAE Congress: Agri-Food and Rural Innovations for Healthier Societies. Ljubljana, Slovenia; 2014. 